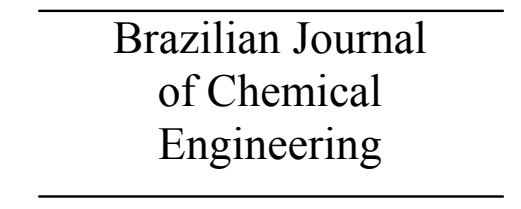

ISSN 0104-6632

Printed in Brazil

www.abeq.org.br/bjche

Vol. 26, No. 02, pp. 399 - 405, April - June, 2009

\title{
DECOLORIZATION OF A TEXTILE DYE, REACTIVE RED 198 (RR198), BY Aspergillus parasiticus FUNGAL BIOSORBENT
}

\author{
S. Tunali Akar ${ }^{1 *}$, T. Akar ${ }^{1}$ and A. Çabuk ${ }^{2}$ \\ ${ }^{1}$ Department of Chemistry, Faculty of Arts and Science, Phone: + (90) (222) $2393750 / 2862$, \\ Fax: + (90) (222) 2393578, Eskişehir Osmangazi University, 26480, Eskişehir, Turkey. \\ E-mail: stunali@ogu.edu.tr \\ ${ }^{2}$ Department of Biology, Faculty of Arts and Science, \\ Eskişehir Osmangazi University, 26480, Eskişehir, Turkey.
}

(Submitted: October 7, 2005 ; Revised: January 24, 2006 ; Accepted: February 2, 2006)

\begin{abstract}
The decolorization potential of textile dye Reactive Red 198 (RR198) by Aspergillus parasiticus fungal biosorbent has been investigated as a function of initial $\mathrm{pH}$, contact time, biosorbent and initial dye concentration in a batch system. Maximum dye biosorption capacity $1.03 \times 10^{-4} \mathrm{~mol} \mathrm{~g}^{-1}$ was observed at $\mathrm{pH} 2.0$ and $2.0 \mathrm{~g} \mathrm{~L}^{-1}$ of biosorbent concentration. Biosorption equilibrium was attained within $50 \mathrm{~min}$. The equilibrium data followed Langmuir, Freundlich and Dubinin-Radushkevich isotherm models at 20,30, 40 and $50^{\circ} \mathrm{C}$. An increase in the biosorption capacity of $A$. parasiticus with temperature showed that the decolorization process is endothermic. Results indicated that Aspergillus parasiticus was an effective candidate for textile dye RR198 removal from aqueous solutions.

Keywords: Aspergillus parasiticus; Biosorption; Decolorization; Isotherm; Reactive Red 198.
\end{abstract}

\section{INTRODUCTION}

As a result of many industrial activities, the discharge of large quantities of organic pollutants into the receiving waters has caused significant environmental pollution. Synthetic dyes are a group of organic pollutants that are extensively used in textile, paper, printing and dyehauses (Aksu, 2005).

The colored effluents damage the aesthetic quality of water and reduce light penetration and photosynthesis and also some of the dyes are toxic or mutagenic, carcinogenic and allergenic (Aksu and Çağatay, 2006; Kumar et al., 2006; Bakshi et al., 1999; O'Mahony et al., 2002). According to the survey of the Ecological and Toxicological Association of the Dyestuffs Manufacturing Industry (ETAD), over $90 \%$ of some 4000 dyes have $\mathrm{LD}_{50}$ values greater than $2000 \mathrm{mg} \mathrm{kg} \mathrm{mg}^{-1}$ (Shore, 1996; Robinson et al., 2001). Hence decolorization of the dye-bearing effluents is of great importance.

The traditional physical or chemical decolorization methods including coagulation, flocculation, ion exchange, irradiation, precipitation, ozonation and adsorption or a combination of these methods have been used for dye removal from wastewaters (Aksu, 2005; Fu and Viraraghavan, 2001).

However application of these methods is somewhat restricted due to some limitations such as operational costs, formation of hazardous byproducts, intensive energy requirement (Padmesh et al., 2005) and limited adaptability to a wide range of effluents (Fu and Viraraghavan, 2001). The use of biological materials as sorbents for the treatment of colored effluents appeared as a potential alternative process to conventional methods (Kumar et al., 2006). Currently, numerous studies have focused on the dye biosorption and biodegradation abilities of microorganisms, including some bacteria, fungi and algae. Live and dead forms of microbial cells can be used in the decolorization process and the main mechanisms of these forms are biodegradation and biosorption, respectively (Fu and Viraraghavan, 2001).

In many treatment processes, compared with the living cells, the dead cells offer some advantages,

*To whom correspondence should be addressed 
which are following; dead organisms are not subject to toxicity limitations, they do not require a continuous supply of nutrients, they can be regenerated simply and reused for many cycles (Akar and Tunali, 2005; Padmesh et al., 2005), biomass can be stored until the use and their operation is easy. Also they can be obtained from industrial sources as a waste product from established fermentation processes ( $\mathrm{Fu}$ and Viraraghavan, 2001).

Compounds such as chitin, lipids, amino acids and other cellular components present on the cell walls of microorganisms provide active binding sites for dye molecules and biosorption processes based on interactions between the dyes and binding sites in a manner of surface adsorption, ion exchange, complexation, chelatation and microprecipitation (Aksu, 2001).The dye-microorganism interactions depend on different factors varying from the chemical structure of the dye being studied to the type of biosorbent used, as well as operating conditions (Kargi and Ozmihc1, 2004; Šafař́ková et al., 2005).

Currently research is focused on finding optimal microbial biosorbent and reaction conditions in order to develop optimal processes enabling decolorization of large volumes of waters (Šafaříková et al., 2005).

The water-soluble reactive dyes are one of the most important groups of dyes used in the textile dyeing industries due to their highly brilliant colors (Aksu, 2003). Reactive Red 198 (RR198) is also among this group of dyes and it was selected as the model reactive dye for this work.

Aspergillus parasiticus and Aspergillus flavus fungal strains have only limited parasitic abilities, yet they can successfully colonize and produce aflatoxin in developing host tissue in the field (Brown et al., 1999; Mayer et. al., 2003). However, several studies have been reported in the literature on the biosorption potential of the dead form of $A$. flavus (Hafez, et al., 1997; Deepa et al, 2006; Akar and Tunali, 2006). The commercially available and easily cultivable fungus $A$. parasiticus was chosen as a biosorbent material because of a lack of information on its dye sorption ability.

This research aims to investigate the removal of a textile dye RR198 from aqueous solutions by $A$. parasiticus cells as an alternative biosorbent. The effects of various operating parameters were studied including $\mathrm{pH}$, biosorbent dosage and contact time. Biosorption was analyzed by the Freundlich, Langmuir and Dubinin-Radushkevich (D-R) isotherm models at $20,30,40$ and $50^{\circ} \mathrm{C}$.

\section{MATERIALS AND METHODS}

\section{Biosorbent Preparation}

The filamentous fungus, A. parasiticus (NRRL 502), was obtained from the culture collection of the Biology Department of Eskişehir Osmangazi University. The stock cultures were routinely maintained on agar medium at $+4^{\circ} \mathrm{C}$ and liquid growth conditions for $A$. parasiticus were described in our previous studies (Kiran, et al., 2005).

The live $A$. parasiticus cells were separated from the growth medium by filtration after seven days of growth, spread on petri dishes and dried in an oven at $60^{\circ} \mathrm{C}$ overnight. They were then powdered using a mortar and pestle and sieved to select $150 \mu \mathrm{m}$ particles for use as a biosorbent.

\section{Dye Solutions}

The dye used in this study was Reactive Red 198 (RR198) obtained from a local textile company and used without further purification. Its chemical structure is shown in Fig. 1. A stock solution $(1 \mathrm{~g}$ $\mathrm{L}^{-1}$ ) of RR198 was prepared by dissolving an accurate quantity of dye in bidistilled water and other concentrations varying between 100 and $300 \mathrm{mg} \mathrm{L}^{-1}$ were obtained by dilution. Fresh dilutions were used for each biosorption experiment. The $\mathrm{pH}$ of the working solutions was adjusted to the required values by $0.1 \mathrm{M} \mathrm{HCl}$ or $0.1 \mathrm{M} \mathrm{NaOH}$. All the chemicals used were analytical grade.

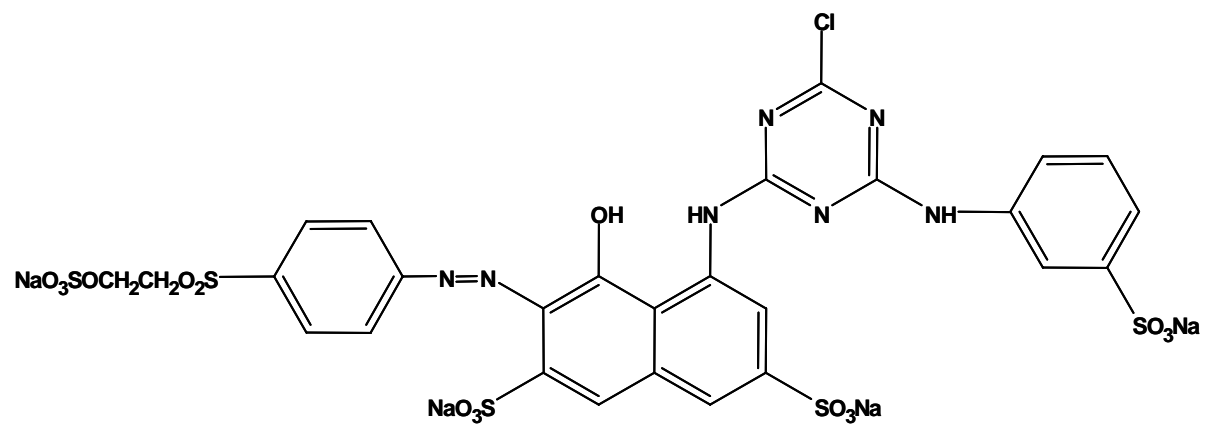

Figure 1: Chemical structure of RR198 


\section{Dye Biosorption Experiments}

Dye biosorption experiments were performed on a magnetic stirrer. $0.1 \mathrm{~g}$ of dried biosorbent of $A$. parasiticus was put in a $100 \mathrm{~mL}$ beaker and $50 \mathrm{~mL}$ of dye solution (100 mg L $\left.{ }^{-1}\right)$ was added to it. The mixture was stirred at $200 \mathrm{rpm}$ at $20^{\circ} \mathrm{C}$ for $1 \mathrm{~h}$ to elucidate the optimum conditions of $\mathrm{pH}$, biosorbent dosage and contact time.

The effect of solution $\mathrm{pH}$ on dye biosorption capacity of the fungal biosorbent was determined by adjusting the $\mathrm{pH}$ values between 1 and 10 , adding freshly prepared $0.1 \mathrm{M} \mathrm{HCl}$ or $0.1 \mathrm{M} \mathrm{NaOH}$ solutions. The optimum $\mathrm{pH}$ value was used throughout all biosorption experiments. The effect of biosorbent concentration was investigated by using biosorbent samples ranging from 0.4 to $4.0 \mathrm{~g} \mathrm{~L}^{-1}$. This was followed by the assessment of the effect of equilibrium time, varied between 10 to $90 \mathrm{~min}$, on the dye biosorption capacity of the biosorbent. The initial dye concentration was varied from 100 to 300 $\mathrm{mg} \mathrm{L}^{1}$ and the isotherm appropriateness of the biosorption results was evaluated for the Langmuir, Freundlich and Dubinin-Radushkevich (D-R) isotherm models at temperatures of 20, 30, 40 and $50^{\circ} \mathrm{C}$ under the optimum conditions.

The biosorption yield (\%) and the amount of dye sorbed by the biosorbent were calculated using the following general equations:

Biosorption yield $(\%)=\left[\left(\mathrm{C}_{\mathrm{i}}-\mathrm{C}_{\mathrm{e}}\right) \cdot 100\right] / \mathrm{C}_{\mathrm{i}}$

$\mathrm{q}_{\mathrm{e}}=\left[\left(\mathrm{C}_{\mathrm{i}}-\mathrm{C}_{\mathrm{e}}\right) \cdot \mathrm{V}\right] / \mathrm{M}$

where,

$\mathrm{q}_{\mathrm{e}}$ : amount of dye biosorbed $\left(\mathrm{mg} \mathrm{g}^{-1}\right)$

$\mathrm{C}_{\mathrm{i}}$ : initial dye concentration in solution $\left(\mathrm{mg} \mathrm{L}^{-1}\right)$

$\mathrm{C}_{\mathrm{e}}$ : final dye concentration in solution $\left(\mathrm{mg} \mathrm{L}^{-1}\right)$

$\mathrm{V}$ : volume of the medium (L)

$\mathrm{M}$ : amount of the biosorbent used in the reaction mixture (g).

Biosorbent was separated by centrifugation at
$500 \mathrm{rpm}$ for $5 \mathrm{~min}$. The dye concentrations in the supernatants were determined using a spectrophotometer, (UV/Vis, Unicam UV2-100) at $\lambda_{\max } 515 \mathrm{~nm}$. All the experiments were carried out in triplicate and data presented are the mean values from these independent experiments. Error bars are indicated wherever necessary. All statistical analysis was done using SPSS 9.05 for Windows.

\section{RESULT AND DISCUSSION}

\section{Effect of pH}

The $\mathrm{pH}$ value of the biosorption medium significantly influences the sorption properties of fungal biosorbents (Aksu and Tezer, 2000). The $\mathrm{pH}$ dependence of dye biosorption is related to both protonation or deprotonation of the functional groups of the biopolymers on the biosorbent surface and the ionization potential of complex dye molecules in solution (Maurya et al., 2006). Fig. 2 represents the effect of $\mathrm{pH}$ on the biosorption of RR198 onto dried A. parasiticus cells. As seen in this figure, the maximum biosorption of RR198 on A. parasiticus was found as $47.56 \mathrm{mg} \mathrm{g}^{1}$ at $\mathrm{pH} 2.0$. Because dye binding sites on the biosorbent were closely associated with $\mathrm{H}_{3} \mathrm{O}^{+}$at lower $\mathrm{pH}$, which cause an increase in the electrostatic attraction between positively charged biosorbent surface and the negatively charged dye molecules. The biosorption capacity of the dried cells of $A$. parasiticus decreased when the $\mathrm{pH}$ of the solution increased from 2.0 to 5.0. Under alkaline conditions biosorption capacity significantly decreased $(p<0.05)$. The decrease of the biosorption capacity with increase in the medium $\mathrm{pH}$ can be explained by the dye binding sites on the biosorbent surface becoming negatively charged, restricting the approach of the dye molecules as a result of repulsive forces.

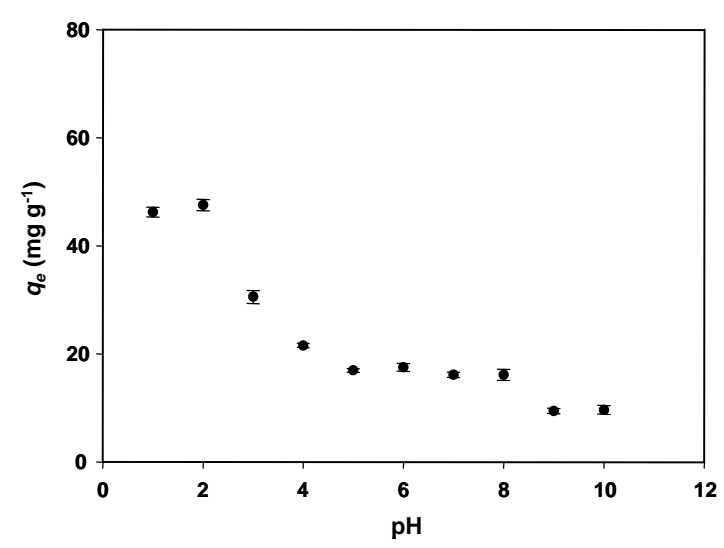

Figure 2: Effect of $\mathrm{pH}$ on the biosorption of RR198 by $A$. parasiticus at $20^{\circ} \mathrm{C}$ 


\section{Effect of Biosorbent Dosage}

In order to determine the effect of the biosorbent dosage on the biosorption efficiency of RR198, the amounts of biosorbent added into the biosorption medium were varied from 0.4 to $4.0 \mathrm{~g} \mathrm{~L}^{-1}$ and the results are presented in Fig 3. With increase in the biosorbent dosage, from 0.4 to $2.0 \mathrm{~g} \mathrm{~L}^{-1}$, the percentage decolorization of RR198 increased from $29.40 \%$ to $98.57 \%$, which is the maximum value obtained as the number of possible binding sites increased. Further increase up to $4.0 \mathrm{~g} \mathrm{~L}^{-1}$ did not change the maximum RR198 biosorption capacity of the biosorbent and it almost stayed constant $(p>0.05)$. This is because, at higher biosorbent concentrations, there is a very fast biosorption onto the biosorbent surface that produces a lower solute concentration in the solution than when the biosorbent concentration is lower (Kumar et al., 2006).

\section{Effect of Contact Time}

Fig. 4 indicates the effect of treatment time on the biosorption of RR198 dye onto biosorbent. High biosorption rates were observed at the beginning of

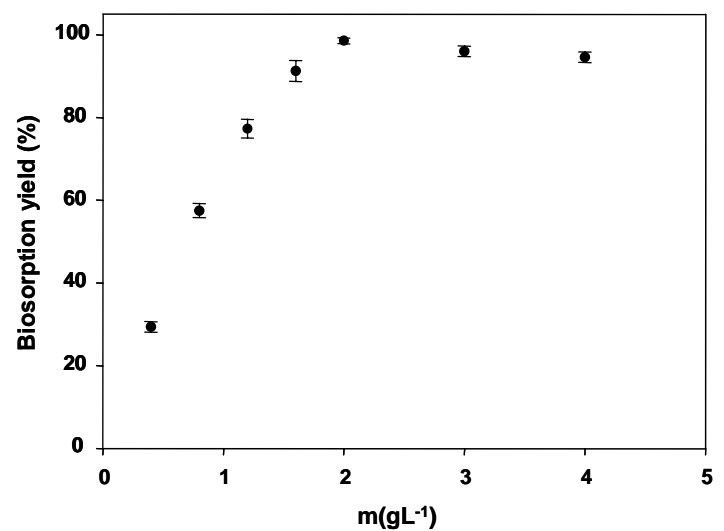

Figure 3: Effect of biosorbent dosage on the biosorption of RR198 by $A$. parasiticus at $20^{\circ} \mathrm{C}$ the biosorption and the process reached the plateau values within ca. $50 \mathrm{~min}$. After this period, no considerable change was observed in the RR198 biosorption capacity of the biosorbent $(p>0.05)$ and it was fixed as the optimum contact time.

\section{Biosorption Isotherms}

Equilibrium isotherms are plots of the quantity of sorbate retained on the biosorbent $\left(q_{e}\right)$ as a function of sorbate concentration in the liquid phase $\left(C_{e}\right)$. Biosorption data are commonly represented by an equilibrium isotherm. The equilibrium biosorption isotherm is of fundamental importance for the design and optimization of the biosorption system for the dye decolorization studies (Maurya et al., 2006). Therefore, the equilibrium biosorption isotherms are one of the most important data for understanding the mechanism of the biosorption (Tunali et al., 2006). Several isotherm equations are available and three important isotherm models, namely Langmuir, Freundlich and Dubinin-Radushkevich (D-R) isotherm models were chosen in this study to describe the biosorption equilibrium and the model plots at various temperatures are shown in Figs. 5, 6 and 7.

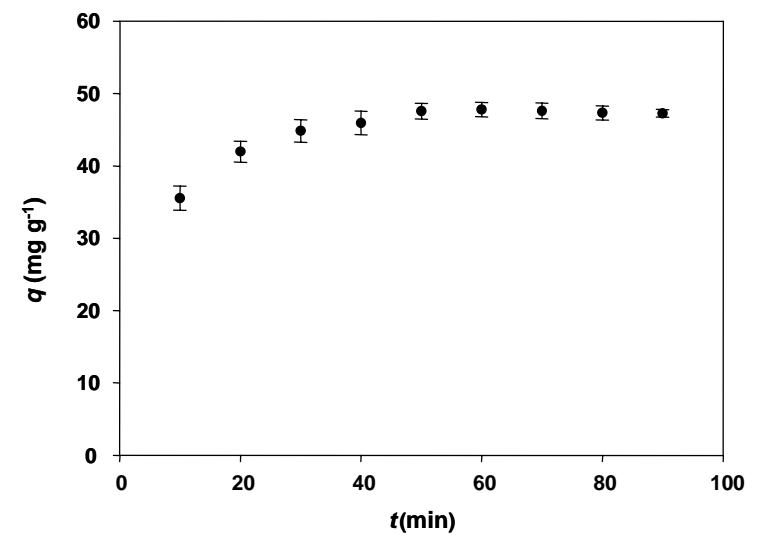

Figure 4: Effect of contact time on the biosorption of RR198 by $A$. parasiticus at $20^{\circ} \mathrm{C}$

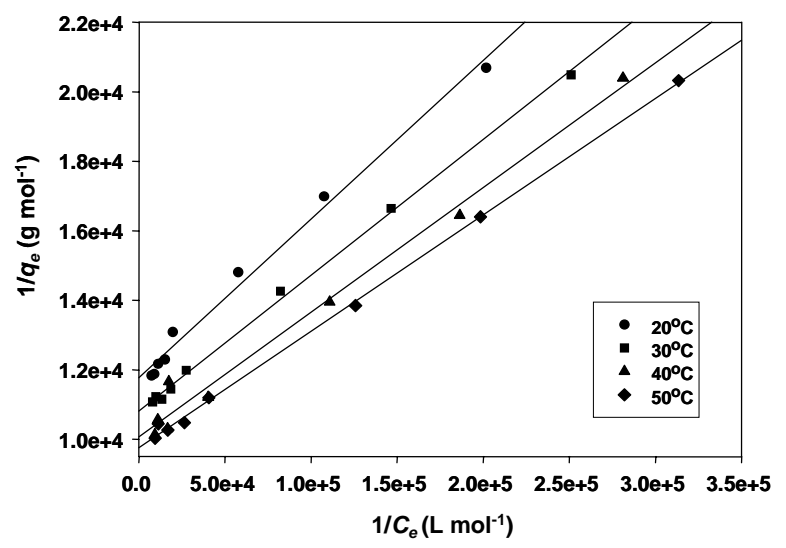

Figure 5: Langmuir plots for the biosorption of RR198 by A. parasiticus at various temperatures 


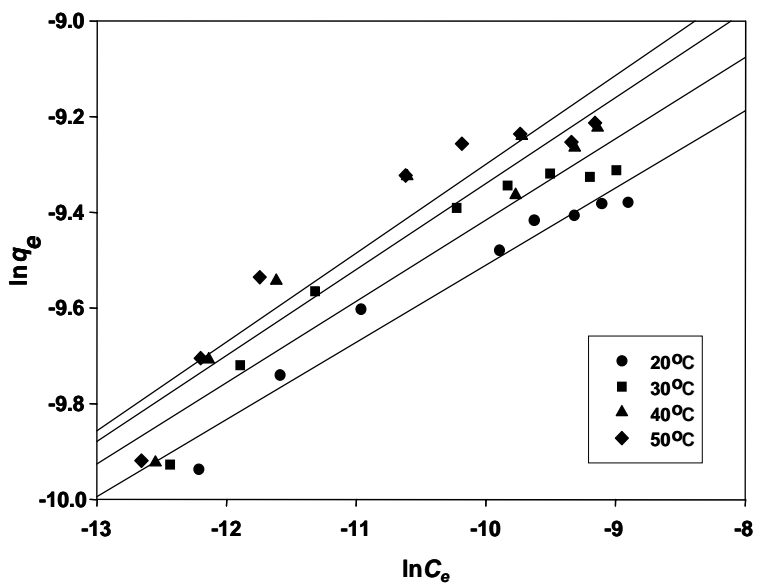

Figure 6: Freundlich plots for the biosorption of RR198 by $A$. parasiticus at various temperatures

The Langmuir isotherm is represented by the following equation (Langmuir, 1918):

$$
\mathrm{q}_{\mathrm{e}}=\frac{\mathrm{q}_{\max } \mathrm{K}_{\mathrm{L}} \mathrm{C}_{\mathrm{e}}}{1+\mathrm{K}_{\mathrm{L}} \mathrm{C}_{\mathrm{e}}}
$$

where $q_{e}$ is the biosorbed dye concentration (mol $\mathrm{g}^{-}$ $\left.{ }^{1}\right), C_{e}$ is the residual dye concentration at equilibrium $\left(\mathrm{mol} \mathrm{L}{ }^{-1}\right), q_{\max }$ is the monolayer biosorption capacity of the biosorbent $\left(\mathrm{mol} \mathrm{g}^{-1}\right)$, and $K_{L}$ is the Langmuir biosorption constant $\left(\mathrm{L} \mathrm{mol}^{-1}\right)$.

The Freundlich isotherm involves heterogeneous biosorption and the empirical Freundlich equation is (Freundlich, 1906):

$\mathrm{q}_{\mathrm{e}}=\mathrm{K}_{\mathrm{F}} \mathrm{C}_{\mathrm{e}}^{1 / \mathrm{n}}$

where $K_{F}\left(\mathrm{~L} \mathrm{mg}^{-1}\right)$ and $n$ are Freundlich biosorption isotherm constants depend on several environmental factors.

The Dubinin-Radushkevich (D-R) isotherm is another less commonly used model. It was applied to distinguish between physical and chemical biosorption (Benhammou et al., 2005) of dye. The D-R isotherm equation (Dubinin and Radushkevich, 1947) is:

$$
\mathrm{q}_{\mathrm{e}}=\mathrm{q}_{\mathrm{m}} \mathrm{e}^{-\beta \varepsilon^{2}}
$$

where $q_{m}$ is the theoretical sorption capacity, and $\varepsilon$ is the Polanyi potential; $\beta\left(\mathrm{mol}^{2} \mathrm{~J}^{-2}\right)$, is the activity coefficient related to mean sorption energy, $E(\mathrm{~kJ}$

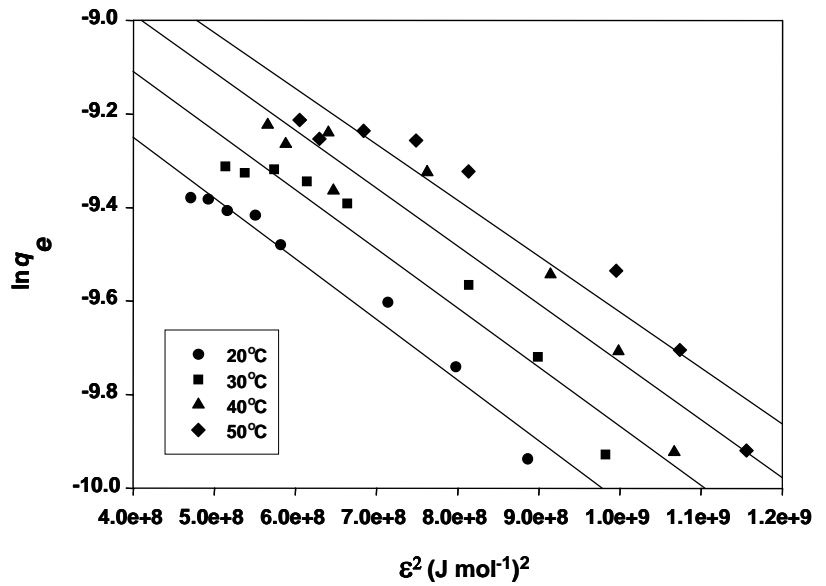

Figure 7: D-R plots for the biosorption of RR198

by $A$. parasiticus at various temperatures

$\mathrm{mol}^{-1}$ ). This is the free energy of the transfer per mole of the biosorbate from infinity to the sorbent surface and can be calculated using the following equation (Hobson, 1969; Hasany and Chaudhary, 1996; Dubey and Gupta, 2005):

$E=\frac{1}{(2 \beta)^{1 / 2}}$

The magnitude of this parameter is useful for information about the type of biosorption process such as chemical ion exchange or physical biosorption. It was found that $E$ values varied from 19.634 to $20.455 \mathrm{~kJ} \mathrm{~mol}^{-1}$, which are bigger then the energy range of adsorption reactions, 8-16 $\mathrm{kJ} \mathrm{mol}^{-1}$. The type of biosorption may be interpreted as chemical biosorption (Helfferich, 1962; Onyango et al., 2004).

The Langmuir, Freundlich and D-R parameters for the biosorption of RR198 dye onto A. parasiticus are listed in Table 1. The Langmuir isotherm model fits very well for the RR198 biosorption process based on the $\mathrm{r}^{2}$ values in Table 1 . Biosorption capacity of $A$. parasiticus increased with increasing temperature from 20 to $50^{\circ} \mathrm{C}$ and was found to be $1.03 \times 10^{-4} \mathrm{~mol} \mathrm{~g}^{-1}$ at $50^{\circ} \mathrm{C}$. This observation implies that the biosorption of RR198 by $A$. parasiticus biosorbent is endothermic nature. The biosorption capacity of $A$. parasiticus obtained for RR198 in this study is comparable to and moderately higher than that of many corresponding biosorbents reported in the literature (Table 2).

Table 1: Biosorption isotherm constants for the biosorption of RR198 by A. parasiticus at various temperatures

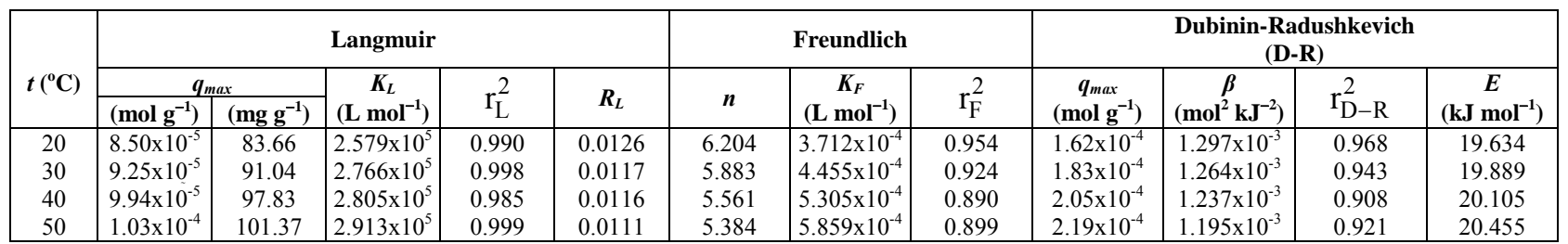


Table 2: Biosorption results of different textile dyes from the literature for various biosorbents and operating conditions

\begin{tabular}{|c|c|c|c|c|c|c|c|}
\hline & & \multicolumn{6}{|c|}{ Rating conditions } \\
\hline Biosorbent material & Dye & pH & $\begin{array}{c}\mathrm{t} \\
\left({ }^{\circ} \mathrm{C}\right)\end{array}$ & $\begin{array}{c}\text { Initial } \\
\text { concentration } \\
\left(\mathrm{mg} \mathrm{L}^{-1}\right)\end{array}$ & $\begin{array}{c}\text { Biosorbent } \\
\text { dosage } \\
\left(\mathrm{g} \mathrm{L}^{-1}\right)\end{array}$ & $\begin{array}{c}\text { Biosorption } \\
\text { capacity } \\
\left(\mathbf{m g ~ g}^{-\mathbf{1}}\right)\end{array}$ & References \\
\hline Rhizopus arrhizus & Reactive Orange 16 & 2.0 & - & $0-500$ & 1.0 & 190 & O’Mahony et al.,2002 \\
\hline Rhizopus arrhizus & Reactive Red 4 & 2.0 & - & $0-500$ & 1.0 & 150 & O’Mahony et al.,2002 \\
\hline Saccharomyces cerevisiae & Remazol Blue & 3.0 & 25 & $10-400$ & 0.52 & 84.6 & Aksu, 2003 \\
\hline Saccharomyces cerevisiae & Remazol Black B & 3.0 & 25 & $10-400$ & 2.87 & 88.5 & Aksu, 2003 \\
\hline Saccharomyces cerevisiae & Remazol Red RB & 3.0 & 25 & $10-400$ & 2.60 & 48.8 & Aksu, 2003 \\
\hline Escherichia coli & Reactive Blue 5 & 3.0 & 28 & 200 & - & 89.4 & $\mathrm{Hu}, 1996$ \\
\hline Escherichia coli & Reactive Red 22 & 3.0 & 28 & 200 & - & 76.6 & $\mathrm{Hu}, 1996$ \\
\hline Escherichia coli & Reactive Violet 2 & 3.0 & 28 & 200 & - & 65.5 & $\mathrm{Hu}, 1996$ \\
\hline Escherichia coli & Reactive Yellow 2 & 3.0 & 28 & 200 & - & 52.4 & $\mathrm{Hu}, 1996$ \\
\hline Aspergillus parasiticus & Reactive Red 198 & 2.0 & 20 & $100-300$ & 2.0 & 83.66 & This study \\
\hline Aspergillus parasiticus & Reactive Red 198 & 2.0 & 50 & $100-300$ & 2.0 & 101.37 & This study \\
\hline
\end{tabular}

The essential characteristics of the Langmuir isotherm can be expressed by a dimensionless constant, $R_{L}$, referred to as the equilibrium parameter. $R_{L}$ is described by the following equation:

$\mathrm{R}_{\mathrm{L}}=\frac{1}{1+\mathrm{K}_{\mathrm{L}} \mathrm{C}_{\mathrm{o}}}$

where $C_{o}$ is the highest dye concentration $\left(\mathrm{mol} \mathrm{L}^{-1}\right)$. The value of $R_{L}$ is used for the interpretation of the sorption type (Weber and Chakravorti, 1974; Hall et al., 1966). Calculated $R_{L}$ values for this study are found to be between 0.0111 and 0.0126 in the temperature range of $20-50^{\circ} \mathrm{C}$ and these results indicate the biosorption process is favorable.

The Freundlich model constants $K_{F}$ and $n$ are indicators of biosorption capacity and biosorption intensity, respectively (Malik, 2004) and the numerical values of these constants are included in Table 1.

\section{CONCLUSION}

A. parasiticus was found to be an effective and alternative biosorbent for the removal of RR198 textile dye from aqueous solutions. The biosorption process was affected by various experimental conditions such as $\mathrm{pH}$, contact time and biosorbent concentration. Maximum dye removal was observed at $\mathrm{pH} 2.0$ and $2.0 \mathrm{~g}$ $\mathrm{L}^{-1}$ of biosorbent concentration. Biosorption equilibrium was established in $50 \mathrm{~min}$. Experimental data were fitted well to the Langmuir isotherm model. The maximum dye removal percentage was determined as $98.57 \%$ at $50^{\circ} \mathrm{C}$. The biosorption process is endothermic.

\section{REFERENCES}

Akar, T. and Tunali, S., Biosorption performance of Botrytis cinerea fungal by-products for removal of $\mathrm{Cd}(\mathrm{II})$ and $\mathrm{Cu}$ (II) ions from aqueous solutions, Miner. Eng. 18, 1099-1109 (2005).

Akar, T. and Tunali, S., Biosorption characteristics of Aspergillus flavus biomass for removal of $\mathrm{Pb}$ (II) and $\mathrm{Cu}$ (II) ions from an aqueous solution, Bioresour. Technol. 97, 1780-1787 (2006).

Aksu, Z., Biosorption of reactive dyes by dried activated sludge: equilibrium and kinetic modelling, Biochem. Eng. J. 7, 79-84 (2001).

Aksu, Z., Reactive dye bioaccumulation by Saccharomyces cerevisae, Process Biochem. 38, 1437-1444, (2003).

Aksu, Z., Application of biosorption for the removal of organic pollutants: a review, Process Biochem. 40, 997-1026 (2005).

Aksu, Z. and Çağatay, Ş. Ş., Investigation of biosorption of Gemazol Turquise Blue-G reactive dye by dried Rhizopus arrhizus in batch and continuous systems, Sep. Purif. Technol. 48, 2435 (2006).

Aksu, Z. and Tezer, S., Equilibrium and kinetic modelling of biosorption of Remazol Black B by Rhizopus arrhizus in a batch system: effect of temperature, Process Biochem. 36, 431-439 (2000).

Bakshi, D. K., Gupta, K. G. and Sharma, P., Enhanged biodecolorization of synthetic textile dye effluent by Phanerochaete chrysosporium under improved culture conditions, World J. Microbiol. Biotechnol. 15, 507-509 (1999).

Benhammou, A., Yaacoubi, A., Nibou, L. and Tanouti, B., Adsorption of metal ions onto Moroccan stevensite: kinetic and isotherm studies, J. Colloid Interface Sci. 282, 320-326 (2005).

Brown, M. P., Brown-Jenco, C. S. and Payne, G. A., Genetic and molecular analysis of aflatoxin 
biosynthesis, Fungal Genet. Biol. 26, 81-98 (1999).

Bustard, M., McMullan, G. and McHale, A.P., Biosorption of textile dyes by biomass derived from Kluyveromyces marxianus IMB3, Bioprocess Eng. 19, 427-430 (1998).

Deepa, K. K., Sathishkumar, M., Binupriya, A. R., Murugesan, G. S., Swaminathan, K. and Yun, S. E., Sorption of $\mathrm{Cr}(\mathrm{VI})$ from dilute solutions and wastewater by live and pretreated biomass of Aspergillus flavus, Chemosphere. 62, 833-840 (2006).

Dubey, S. S. and Gupta, R. K., Removal behavior of Babool bark (Acacia nilotica) for submicro concentrations of $\mathrm{Hg}^{2+}$ from aqueous solutions: a radiotracer study, Sep. Purif. Technol. 41, 21-28 (2005).

Dubinin, M. M. and Radushkevich, L.V., Equation of the characteristic curve of activated charcoal, Proceedings of the Academy of Sciences, Physical Chemistry Section, U.S.S.R. 55, 331-333 (1947).

Freundlich, H. M. F., Über die adsorption in lösungen, Z. Phys. Chem. 57, 385-470 (1906).

$\mathrm{Fu}, \mathrm{Y}$. and Viraraghavan, T., Fungal decolorization of dye wastewaters: a review, Bioresour. Technol. 79, 251-262 (2001).

Hafez, N., Abdel-Razek, A. S. and Hafez, M. B., Accumulation of some heavy metals on Aspergillus flavus, J. Chem. Tech. Biotechnol. 68, 19-22 (1997).

Hall, K. R., Eagleton, L. C., Acrivos, A. and Vermeulen, T., Pore- and solid-diffusion kinetics in fixed-bed adsorption under constant-pattern conditions, Ind. Eng. Chem. Fundam. 5, 212-223 (1966).

Hasany, S. M. and Chaudhary, M. H., Sorption potential of Hare River sand for the removal of antimony from acidic aqueous solution, Appl. Radiat. Isot. 47, 467-471 (1996).

Helfferich, F., Ion Exchange, McGraw-Hill, New York (1962).

Hobson, J. P., Physical adsorption isotherms extending from ultrahigh vacuum to vapor pressure, J. Phys. Chem. 73, 2720-2727 (1969).

$\mathrm{Hu}, \mathrm{T}-\mathrm{L}$. , Removal of reactive dyes from aqueous solution by different bacterial genera, Water Sci. Technol. 34, 89-95 (1996).

Kargi, F. and Ozmıhc1, S., Biosorption performance of powdered activated sludge for removal of different dyestuffs, Enzyme Microb. Technol. 35, 267-271 (2004).

Kiran, I., Akar, T. and Tunali, S., Biosorption of $\mathrm{Pb}$ (II) and $\mathrm{Cu}$ (II) from aqueous solutions by pretreated biomass of Neurospora crassa, Process Biochem. 40, 3550-3558 (2005).
Kumar, K. V., Ramamurthi, V. and Sivanesan, S., Biosorption of malachite green, a cationic dye onto Pithophora sp., a fresh water algae, Dyes Pigments. 69, 102-107 (2006).

Langmuir, I., The adsorption of gases on plane surfaces of glass, mica and platinum, J. Am. Chem. Soc. 40, 1361-1403 (1918).

Malik, P. K., Dye removal from wastewater using activated carbon developed from sawdust: adsorption equilibrium and kinetics, J. Hazard. Mater, 113:81-88 (2004).

Maurya, N. S., Mittal, A. K., Cornel, P. and Rother, E., Biosorption of dyes using dead macro fungi: effect of dye structure, ionic strength and $\mathrm{pH}$, Bioresour. Technol. 97, 512-521 (2006).

Mayer, Z., Bagnara, A., Färber, P. and Geisen, R., Quantification of the copy number of nor- 1 , a gene of the aflatoxin biosynthetic pathway by real-time PCR, and its correlation to the cfu of Aspergillus flavus in foods, Int. J. Food Microbiol. 82, 143-151 (2003).

O'Mahony, T., Guibal, E. and Tobin, J. M., Reactive dye biosorption by Rhizopus arrhizus biomass, Enzyme Microb. Technol. 31, 456-463 (2002).

Onyango, M. S., Kojima, Y., Aoyi, O., Bernardo, E.C. and Matsuda, H., Adsorption equilibrium modeling and solution chemistry dependence of fluoride removal from water by trivalent-cationexchanged zeolite F-9, J. Colloid Interface Sci. 279, 341-350 (2004).

Padmesh, T. V. N., Vijayaraghavan, K., Sekaran, G. and Velan, M., Batch and column studies on biosorption of acid dyes on fresh water macro algae Azolla filiculoides, J. Hazard. Mater. 125, 121-129 (2005).

Robinson, T., McMullan, G., Marchant, R. and Nigam, P., Remediation of dyes in textile effluent: a critical review on current treatment technologies with a proposed alternative, Bioresour. Technol. 77, 247-255 (2001).

Šafař́ková, M., Ptáčková, L., Kibriková, I. and Šafaŕík, I., Biosorption of water-soluble dyes on magnetically modified Saccharomyces cerevisiae subsp. uvarum cells, Chemosphere 59, 831-835 (2005).

Shore, J., Advances in direct dyes, Indian J. Fib. Text. Res. 21, 1-29 (1996).

Tunali, S., Akar, T., Özcan, A. S., Kiran, I. and Özcan, A., Equilibrium and kinetics of biosorption of lead (II) from aqueous solutions by Cephalosphorium aphidicola, Sep. Purif. Tehnol. 47, 105-112 (2006).

Weber, W. J. and Chakravorti, R. K., Pore and solid diffusion models for fixed-bed adsorbers, J. Am. Inst. Chem. Eng. 20, 228-238 (1974). 